\title{
Insurgency in Northern Nigeria: Implication for Polio Eradication in Nigeria
}

\section{Dr Olorunfemi Akinbode OGUNDELE ${ }^{1}$, Dr Christianah Adeola ADEYANJU², and Dr Ayodeji Andrew OMOTOSO²}

${ }^{1}$ Department of Community Medicine, University of Medical Sciences, Ondo City, Ondo State ${ }^{2}$ Department of Community Health, University of Medical Sciences Teaching Hospital, Ondo City, Ondo State

Corresponding Author:

Dr Olorunfemi Akinbode OGUNDELE;

email: femiaoo@yahoo.com

Received 23 August 2019

Accepted 14 December 2019

Published 30 December 2019

Production and Hosting by

Knowledge E

(a) Dr Olorunfemi Akinbode OGUNDELE et al. This article is distributed under the terms of the Creative Commons Attribution License, which permits unrestricted use and redistribution provided that the original author and source are credited.

Editor-in-Chief:

Prof. Mohammad A. M. Ibnouf

\section{G OPEN ACCESS}

\section{Abstract}

Northern Nigeria is currently threatened by two wars, the disease called polio and insurgency caused by the fierce group that rejects the influence of Western education. The increased insurgency experienced in the last decade in the form of violent conflicts and criminality has created a community of poor internally displaced people at risk of infectious diseases such as polio. Despite efforts by the government to eradicate polio in Nigeria insurgency remain a major obstacle. There is a need to urgently tackle insurgency to achieve polio eradication.

\section{Introduction}

Northern Nigeria is confronted by two wars, the disease, and the insurgency caused by the brutal rebels who reject the influence of western education [1]. Insurgency is defined as an organized movement aiming at overthrowing a constituted authority or government through a disruptive means and armed conflict [2]. This definition means that insurgent groups employ unlawful means towards achieving an end, which could be political, religious, social or even ideological. The disease is Polio a plague on the poor, a paralyzing, disabling brute of a virus, it deforms the limbs and wastes the muscles. Children under five are most at risk and places with poor sanitation are favoured feeding grounds for the virus, which spreads through infected faeces [1]. The increased insurgency experienced in the last decade in form of violent conflicts and criminality has created a community of poor internally displaced people that runs into millions. This community is a veritable ground where polio can thrive. The major insurgency group is Boko Haram. The group started in 2009 as an agitation against western Influence of any kind. The sect which started it activities in one of the state now holds a great swath of territory in north-east Nigeria. Aside resisting western civilization and education the sect shield people in its territory and keep vaccination teams seen as a western influence out. Their leaders also share distrust with repeated allegations that the polio vaccine was a western plot to sterilize the people. It is to this area that polio has returned, and 
the fear is that those fleeing their violence could bring the virus back into the wider country. Nigeria was on track to be declared polio-free in 2017 among the remaining three host counties, others being Afghanistan and Pakistan. But just as it was ready to celebrate, the disease recurred. For every one person paralyzed by polio, there is a contagious pool somewhere in the community. Findings show that health indices such as maternal and child health are worst in the Northern zone compared to other region in Nigeria [3]. The 2016 Humanitarian Response Plan report shows that about 14.8 million people in four states (Borno, Yobe, Adamawa, Gombe) were affected by the insurgency with about 7 million in need of humanitarian assistance. Of these, about 3.7 million are in need of health interventions [4]. In 2018, nearly 2 million people are internally displaced with over $80 \%$ of these being in Borno State, the epicenter of the crisis and over $60 \%$ living in host communities [5]. The conflict has no doubt impacted on child health through many pathways especially the breakdown of Infrastructures such as health facilities, markets, water supply and sewage systems. In countries like UK, where polio has long been wiped out, sewers are regularly tested to ensure that polio does not sneak back into the population compared to a displaced population without access to good quality infrastructure, the risk that polio or any other disease would thrive if uncontrolled is increased.

\section{Poliovirus and Vaccine}

There are 3 serotypes of wild Polioviruses and are mainly transmitted through the faecooral route (via stool contaminated food and water) and also by person to person contact. Polio has no cure, clinical cases can only be managed with supportive care. Therefore, prevention is the mainstay of management of polio. Vaccination is the primary mode of prevention, although improvement in hygiene and sanitation standards also play a role. Primary and booster doses of polio vaccine protects most vaccinees for life [6].

Two vaccines are currently available for prevention namely the live attenuated Oral Polio Vaccine (OPV) and the Inactivated (killed) Polio Vaccine (IPV). OPV is safe, but has a rare adverse event called Vaccine-associated paralytic polio (VAPP) that could occur when OPV virus revert to a live virus called circulating vaccine-derived polio viruses (cVDPVs) resulting in paralysis similar to wild polio viruses. On the other hand, IPV has no risk of VAPP and confers immunity against 3 serotypes. 


\section{Insurgency Implication on Polio Eradication}

Nigeria as a country share boundary with other African countries; Lake Chad, Benin republic, Niger republic and Cameroun. This gives access to the spread of disease outbreak through migration in and out of the country.

Immunization activities in northern Nigeria have been significantly limited by security concerns over insurgency which prevented vaccinators from reaching multiple Northern villages over the years, and consequently, many children may not have been immunized. Lack of access to people who settled in the inaccessible area following insurgent attack reduce the immunity in the area compared to other areas thus making large population of children susceptible to the disease. This has led to the build-up of a large susceptible population of children, estimated between 500,000 and 1,000,000 in the inaccessible areas which could serve as a source of transmission [4].

Cases of AFP could go unnoticed as large displaced populations are continuously moving between cities and camps hindering surveillance efforts and pose a risk of transmission to new susceptible individual in the community. This also prevents the ability to track children's vaccination status as many could not be located. Findings revealed that 3 cases detected in $\mathbf{2 0 1 6}$ were found in the area under insurgency control and have the same genetic resemblance to 2011 strain detected in the same area. This shows that the case had been in circulation undetected for five years [7]

Difficulty in reaching mobile population who had moved out of the temporary camps to their original homes following regain of territory by military pose a challenge to polio eradication as OPV doses are supposed to be administered at regular intervals to be effective. Northern states are the home of nomadic groups who graze their cattle across the country and neighboring countries [8] it, therefore, serves as a means of spreading Poliovirus and other diseases to neighboring countries or acquiring a new strain into the country. This situation introduce some complexity into the eradication agenda as it's so difficult to curtail such movement. There is therefore increased risk of re-introduction into a previously free zone in the countries and neighbouring countries. The stumbling block here therefore is not a lack of effort neither is it the drive to vaccinate by Nigeria, but rather the problem of insurgency complicated by underlying culture and religious beliefs which no doubt might delay the polio eradication agenda. 


\section{Conclusion}

In spite of efforts by the government on polio eradication in Nigeria insurgency remain a major barrier. It may be difficult for polio to be eradicated in Nigeria due to persistent insurgency in northern Nigeria and the impact on health, infrastructure and socioeconomic situation of the populace. Urgent attention is required. The government should intensify efforts in curbing the spate of attacks and insecurities and complete restoration of peace and tranquility to the affected communities and states. It is only when there is security of lives and properties together with freedom of movement that success can be recorded on surveillance, tracking of children vaccination status and immunization schedule on poliomyelitis disease. Therefore, access constraints related to insecurity must be effectively tackled for global effort on total polio eradication in Nigeria to be an achievement.

\section{References}

[1] McVeigh, T. (2017). Northern Nigeria is the frontline in two wars: The disease and the brutal rebels who reject the west's influence, The Guardian International Edition, May 7. Retrieved from: https://www.theguardian.com/global-development/2017/may/ 07/nigeria-polio-vaccination-boko-haram (accessed 5 September 2019).

[2] United State Department of Defence. (2007). Retrieved from: http//www.wikipedia. org (accessed 1 September 2019).

[3] National Population Commission, ICF International. (2014). Nigeria demographic and health survey 2013. Abuja: National Population Commission and ICF International.

[4] Polio Global Eradication Initiatives: Nigeria and lake Chad Polio Outbreak Appeal (2016). Retrieved from: http//www.humanitarianResponse.info or http//www. polioeradication.org

[5] The Independent Monitoring Board of the Global Polio Eradication Initiative on Progress in Afghanistan, Nigeria and Pakistan. (2018). A review of polio endemic countries report. Retrieved from: http://polioeradication.org/wp-content/uploads/ 2018/10/Review-of-Polio-Endemic-Countries-2018.pdf (accessed 1 September 2019).

[6] Tagbo, B. N. (2013). Achieving polio eradication in Nigeria: Prospects and challenges. Nigerian Journal of Paediatrics, vol. 1, pp. 15-23. DOI: http://dx.doi.org/10.4314/njp. v40i1.3

[7] McKenna, M. (2016). Polio returns to Nigeria for the first time in years. Retrieved from: https://www.nationalgeographic.com (accessed 1 September 2019). 
[8] McNeil, D. G., Jr. (2016). Polio response in Africa to be fast, difficult and possibly dangerous, The New York Times, August 12, 2016. Retrieved from: http://ift.tt/ 2aX6Djv (accessed 1 September 2019). 